\title{
The youngest trigonotarbid Permotarbus schuberti n. gen., n. sp. from the Permian Petrified Forest of Chemnitz in Germany
}

\author{
Jason A. Dunlop ${ }^{*}, 1$ and Ronny Rößler ${ }^{2}$ \\ ${ }^{1}$ Museum für Naturkunde Berlin, Leibniz-Institut für Evolutions- und Biodiversitätsforschung, Invalidenstraße 43, 10115 Berlin, Germany. \\ E-mail: jason.dunlop@mfn-berlin.de \\ ${ }^{2}$ Museum für Naturkunde Chemnitz, Moritzstraße 20, 09111 Chemnitz, Germany. E-mail: roessler@naturkunde-chemnitz.de
}

Received 15 March 2013

Accepted 3 April 2013

Published 5 August 2013

\begin{abstract}
A new trigonotarbid (Arachnida: Trigonotarbida) is described as Permotarbus schuberti n. gen., n. sp. from the Early Permian Petrified Forest (Rotliegend) of Chemnitz in Saxony (Germany). At ca. $290 \mathrm{Ma}$ it represents the youngest record of this extinct arachnid order discovered to date. Its familial affinities are uncertain, but may lie close to the Aphantomartidae. The distribution of the trigonotarbid genera through time is summarised, together with a list of their seventy-seven fossil-yielding localities. Together they offer a broad overview of the group's fossil record, which is heavily biased towards the Moscovian Stage (ca. 307-312 Ma) of the Late Carboniferous in Europe and North America. This is due in no small part to numerous localities associated with coal mining districts, and trigonotarbids are found less frequently after this stage. While it is tempting to associate this with biological events - such as a putative 'Carboniferous Rainforest Collapse' dating to ca. $305 \mathrm{Ma}$ - it is difficult to differentiate the effects of genuine extinction patterns from artefacts caused by fewer appropriate localities in the economically less relevant latest Carboniferous and Early Permian strata. Nevertheless, trigonotarbids became extinct at some point after the Early Permian and loss of the Coal Measures forests remains one of the most likely possible causes.
\end{abstract}

\section{Introduction}

Trigonotarbids are an extinct order of arachnids with an essentially spider-like appearance, albeit characterised by an opisthosoma in which the dorsal tergites are divided into median and lateral plates; a feature which they share with the rare order Ricinulei. Including incertae sedis taxa, sixty-five valid species of trigonotarbid in thirty-four genera are currently recognised in the literature (Dunlop et al. 2013), and as a group they ranged from the late Silurian through to the Early Permian. While trigonotarbids can be diverse and abundant in the Late Carboniferous across a range of European and North American Coal Measures localities (see e.g. Petrunkevitch 1953), Permian records are extremely rare. They are presently restricted to the Carboniferous-Permian boundary of Bajo de Véliz in Argentina (Pinto \& Hünicken 1980), and a number of localities in the Rotliegend of Thuringia in eastern Germany (Scharf 1924;
Müller 1957; Rößler 1998; Rößler et al. 2003). These German records date to about $295 \mathrm{Ma}$ (Asselian) based on biostratigraphic considerations (Schneider \& Werneburg 2006); although precise geochronological ages are presently lacking. Here, we describe another Permian trigonotarbid this time from the Rotliegend of Chemnitz in the German state of Saxony (Fig. 1). At ca. $290 \mathrm{Ma}$ (Sakmarian) it is the stratigraphically youngest record of a trigonotarbid arachnid to date (Fig. 2). Although its rather coarse state of preservation (Figs 3-4) and the absence of certain details preclude its unequivocal assignment to a family, we tentatively name it as a new genus and species with probable affinities to the family Aphantomartidae.

In the broader context of trigonotarbid geological history, we document visually (Fig. 5) the stratigraphic ranges of the known genera and list localities by age which have yielded fossils of these arachnids (Table 1). Unsurprisingly, this reveals a concentration of records

* Corresponding author 
from the Late Carboniferous associated with numerous productive and often well-studied Coal Measures localities (Fig. 6). These in turn derive from industrial exploitation of coal seams (see Discussion). Trigonotarbids are notably rarer from after the time of the coal swamps. We discuss whether this is part of a genuine loss of diversity - part of a shift towards the eventual extinction of the Trigonotarbida - or an artefact of less accessible and/or less intensively mined rock sequences suitable for their preservation.

\section{Materials and methods}

The holotype and only known specimen of the new trigonotarbid was collected from Early Permian volcaniclastics of the Zeisigwald Tuff horizon, Petrified Forest of Chemnitz, Saxony, Germany (50.85262 N, $12.94616^{\circ}$ E) (Fig. 1). The specimen has been deposited in the Museum für Naturkunde Chemnitz under the repository number TA0932. It was photographed using a Leica stereomicroscope with associated automontage software for combining stacks of images at different focal planes (Leica Application Suite) and drawn using a Leica MZ12 stereomicroscope with a camera lucida attachment. All measurements are given in millimetres. Stratigraphic and locality data for trigonotarbids in general were assembled directly from the primary literature (Table 1). In general the oldest published record from a given locality is presented here as the source reference, although it should be borne in mind that subsequent specimens from these fossil sites may have been described. Stage names and approximate absolute dates in millions of years (Table 1) are based on the 2012 'International Chronostratigraphic Chart' provided by the International Commission on Stratigraphy $<$ http://www.stratigraphy.org $>$.

\section{Preservation and geological setting}

The new fossil is preserved in a purple-red matrix of an approximately $15-20 \mathrm{~cm}$ thick, weakly horizontallybedded and moderately sorted fine to medium-grained ash-tuff (Fig. 2). The pyroclastic material is nonwelded, rich in alterated blocky shards and composed of several normal-graded units. Light grey to green mottling frequently occurs in the vicinity of organic inclusions. This deposit rests sharply upon a variegated palaeosol, and represents a succession that resulted from low-concentration pyroclastic density currents and accompanying fallout during an early stage of volcanic activity in

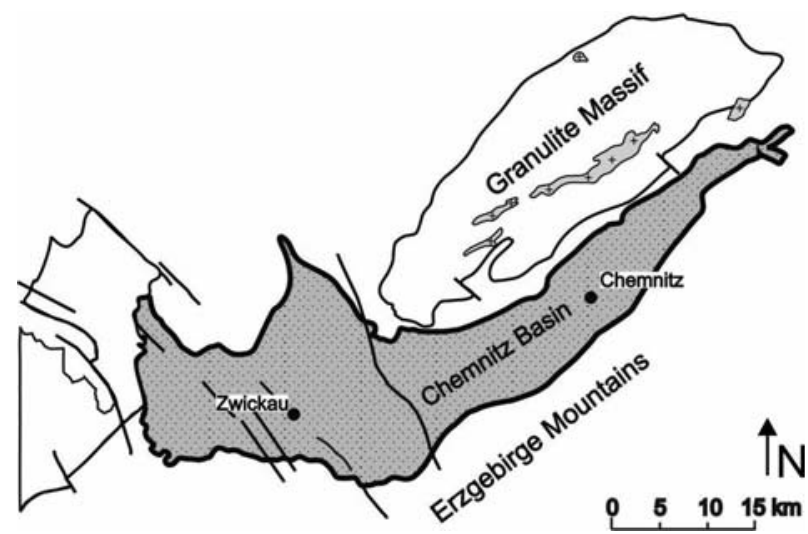

Figure 1. Location map of the fossil site in Chemnitz. the investigation area. The bed from which the new trigonotarbid came represents the lowermost deposit of the Zeisigwald Tuff horizon, Leukersdorf Formation.

Caused by an explosive magmatic to phreatomagmatic eruption, volcanic ashes covered the standing vegetation and were deposited. As a result, many trees shed their leaves, which are found embedded in a layer near the basis of Unit S5 sensu Rößler et al. (2012). Along with leafy shoots, pinnate fronds, detached whole and fragmentary leaves, this horizon has yielded the first outstanding faunal remains. Among them are vertebrates - comprising five reptile skeletons, aistopod microsaurians, and remains of an eryopid amphibian - as well as such invertebrates as diplopods, chilopods, remains of the giant arthropod Arthropleura, various arachnids including trigonotarbids, one uropygid, and many gastropods. Thus, the Chemnitz Petrified Forest provides a window into an almost complete Permian forest ecosystem, preserved in-situ in a geological instant (Rößler et al. 2012). The stratigraphic position of this fossil Lagerstaette corresponds to the early Sakmarian and is thus dated at 290.6 $\pm 1.8 \mathrm{Ma}$ (Stanek, personal communication, 2009). Stratigraphic, geological and taphonomic details were reported in Kretzschmar et al. (2008) and Rößler et al. (2009, 2010, 2012).

\section{Systematic palaeontology}

Order Trigonotarbida Petrunkevitch, 1949

Family uncertain

\section{Permotarbus n. gen.}

Derivation of name. After the stratigraphic occurrence of the type species in the Early Permian Rotliegend of Chemnitz, Germany.

Diagnosis. Trigonotarbids with a subtriangular carapace, raised medially and with lobation of the lateral margins. Unlike the similar-looking Aphantomartus, dorsal body surface without obvious ornament of tubercles or pustules.

Remarks. The coarse nature of the sediment and the equivocal nature of some details - e.g. the complete morphology of the carapace, whether the ninth tergite is divided or entire, and whether the dorsal cuticle was finely ornamented - renders a formal assignment of the new Chemnitz fossil to one of the existing trigonotarbid families difficult. The apparent presence of lateral lobes (Figs 3-4) on a subtriangular carapace tends to rule out most of the (presumably) more basal families, i.e. Palaeocharinidae, Archaeomartidae, Anthracomartidae and Anthracosironidae; none of which have a lobed or subtriangular carapace. Trigonotarbidae also has a subtriangular carapace, which is also medially raised similar to the condition seen in our fossil, but lacks these lateral lobes. Indeed, a distinctly lobed carapace is one of the characters seen in the 'eophrynid assemblage' sensu Dunlop \& Brauckmann (2006) which includes Aphantomartidae, Kreischeriidae and Eophrynidae. In terms of its overall outline and limb robust- 

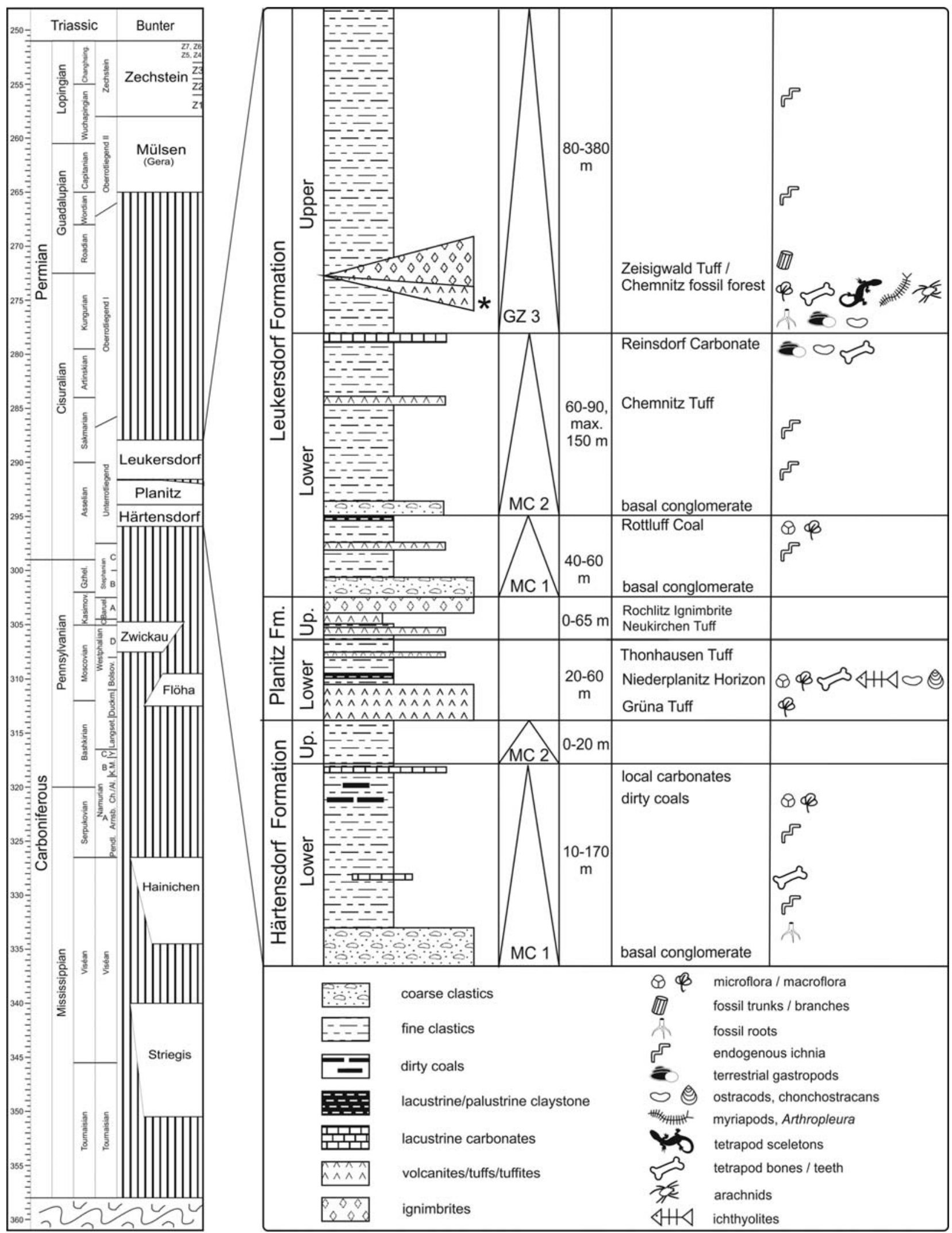

Figure 2. Stratigraphic framework of the fossiliferous horizon, which yielded Permotarbus schuberti n. gen., n. sp.; star indicates the stratigraphic position of the find (adapted from Berger \& Junghanns 2010).

ness the new Chemnitz fossil resembles Aphantomartidae (cf. figures in Rößler 1998). However, all the eophrynid-related trigonotarbids were heavily armoured creatures with distinct pustules, granules or tubercles ornamenting the dorsal body surface. As noted above, the hosting sediment is not conducive to picking up 
fine details of surface structure in the new fossil, but we see no compelling evidence for a highly ornamented dorsal body surface as in the three latter named families.

The leaves the genus Namurotarbus Poschmann \& Dunlop, 2010 from Hagen-Vorhalle in Germany, currently unplaced at family level, and the genus Lissomartus Petrunkevitch, 1949 placed in its own family, Lissomartidae, from Mazon Creek in Illinois, USA; both Late Carboniferous. Although a formal phylogeny of the trigonotarbids is lacking, it is possible that these two genera somehow bridge the morphological gap between the fairly simple-looking Trigonotarbidae and the more heavily armoured eophrynid-like families. In detail, Namurotarbus is a squat and compact animal with a lobed and distinctly triangular carapace, but no tuberculation (Dunlop \& Brauckmann 2006, fig. 2). Lissomartus also has a medially raised carapace and no tuberculation, but the carapace lobation is only hinted at by faint demarcation lines (Dunlop 1995, fig. 3) - as if in the process of first evolving.

Thus although imperfect, our fossil does appear to express a character combination different to what is known from other trigonotarbids; i.e. a lobed and subtriangular carapace, but no pustulate dorsal body ornament (see also Diagnosis). For this reason we name it, with reservations, as a new genus and species and hope that future material will confirm details of its morphol- ogy. We suspect that, like Namurotarbus and Lissomartus, our new fossil probably resolves somewhere towards the base of the 'eophrynid assemblage', but this needs to be formally tested cladistically. Pending this, we are reluctant to create a monotypic family and prefer to leave the position of this genus and species open.

\section{Permotarbus schuberti n. gen., n. sp.}

Figures 3-4

Derivation of the name. In honour of Dr. Peter Schubert, who was involved in the financial support which made the Chemnitz-Hilbersdorf excavation (2008-2011) both possible and successful.

Holotype. Museum für Naturkunde Chemnitz, no. TA 0932 (part and counterpart).

Type locality and horizon. Coordinates SSP-60; leg. Sandra Mehlhorn, 05.11.2010. From the Zeisigwald Tuff horizon, Petrified Forest of Chemnitz, Saxony, Germany. Early Permian (Sakmarian).

Diagnosis. As for the genus.

Description. Part (Fig. 3) and counterpart of an almost complete animal, largely in dorsal view but with ventral elements of the prosoma visible in the (generally less well preserved) counterpart. All measurements in $\mathrm{mm}$. Total preserved length 11.8. Carapace subtriangular in outline, length 3.8, maximum width at base ca. 4.0. Carapace with a raised central region, approximately in
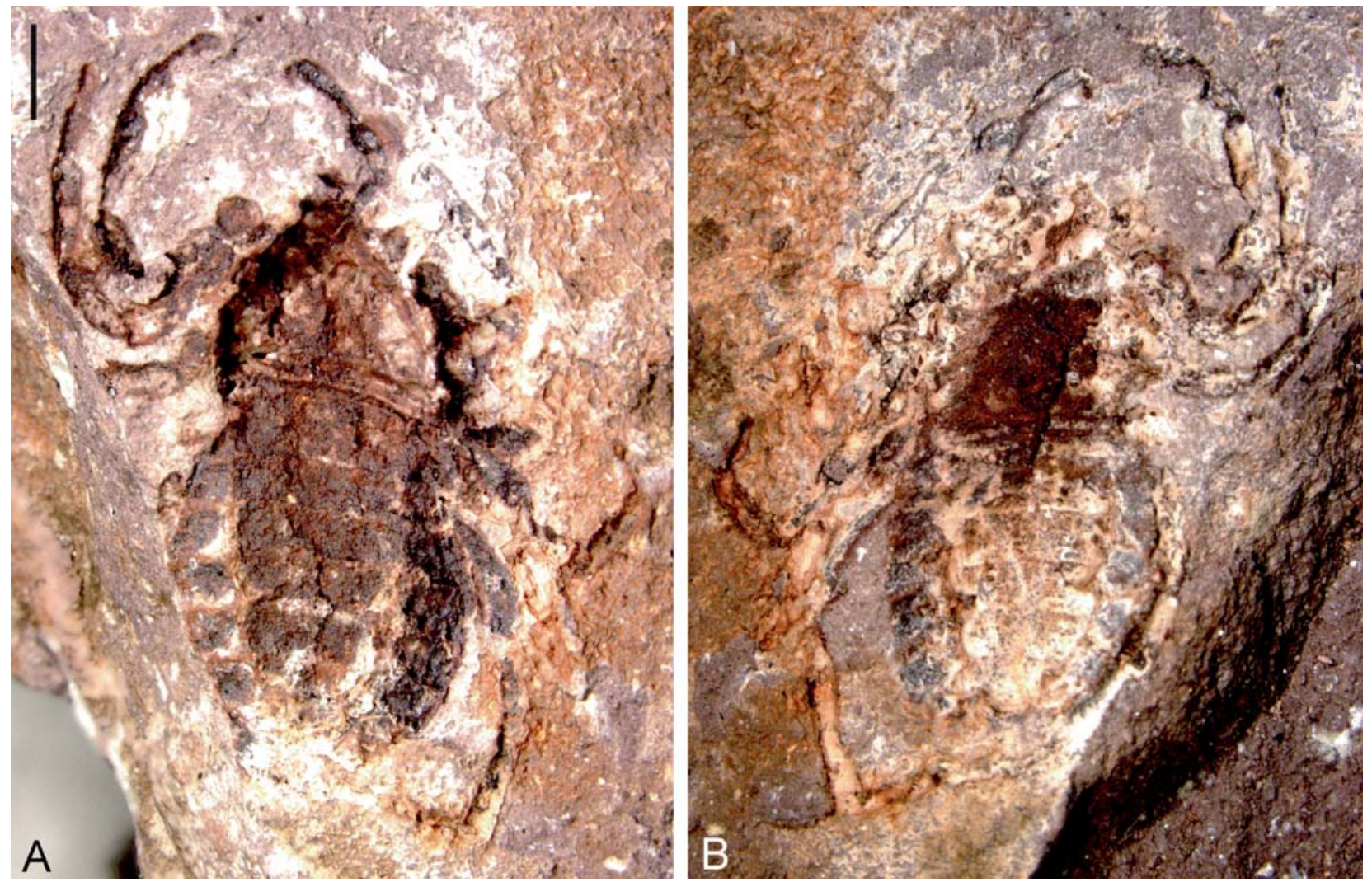

Figure 3. Permotarbus schuberti n. gen., n. sp. Holotype and only known specimen, Museum für Naturkunde Chemnitz, no. TA 0932. A. Part. B. Counterpart. Scale bar equals $2 \mathrm{~mm}$. 


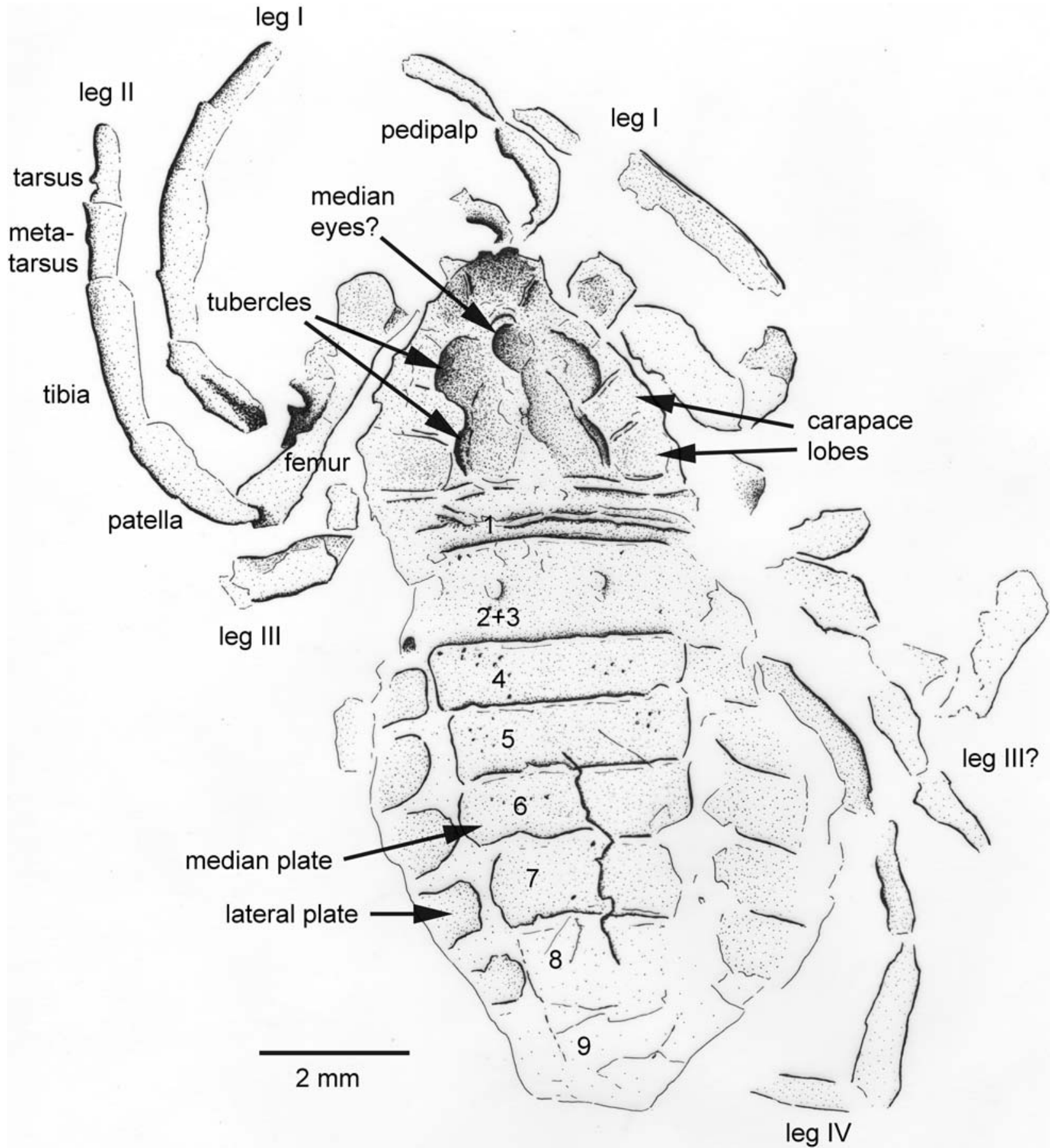

Figure 4. Camera lucida drawing of the holotype of Permotarbus schuberti n. gen., n. sp. part shown in Figure 3A. Scale bar equals $2 \mathrm{~mm}$.

the form of a broad 'hour-glass', maximum width ca. 2.0. Raised area slightly depressed along the midline towards the posterior end. Raised area bears an oval to diamond-shaped tubercle on the midline, length 0.6 , situated in the anterior half of the carapace ca. $1 \mathrm{~mm}$ from the anterior tip; probably the median eye tubercle, but individual lenses not well preserved. Lateral margins of raised, central region seem to merge into depressions in the matrix suggesting the presence of raised, perhaps rather elongate tubercles here in life. Anterior end of carapace (clypeus) apparently with a pair of longitudinal, slightly splaying grooves; carapace tip apparently bilobed. Carapace laterally with evidence of at least two (probably three) pairs of subtriangular lobe-like divisions flanking the raised central area. Carapace cuticle lacks obvious ornament in the form of tubercles or pustules.

Chelicerae equivocal but one pedipalp perhaps represented by a small fragment in front of the carapace. Coxo-sternal region poorly preserved, but appears to show a series of subtriangular coxae surrounding a fairly wide sternal region; sternal plate itself equivocal. 
Legs partially complete; left legs 1 and 2 more or less entire. Legs generally fairly short and robust; trochanters rounded. Articles not always clearly defined, but approximate lengths as follows. Leg 1: femur 1.9; patella 1.6; tibia 2.2; metatarsus 1.2; tarsus 0.7 (total preserved length 7.6). Leg 2: femur 1.4; patella 1.7; tibia 2.0; metatarsus 1.3; tarsus 0.9 (total preserved length 7.3). Legs 3 and 4 probably with similar overall lengths and proportions, but details poor.

Opisthosoma oval, widest more or less in the middle, maximum preserved length 8.0, maximum preserved width 5.9. Tergite 1 present as a short, ca. 0.3 long, element apparently modified into a locking ridge tucked under the carapace ventral margin in life. Remaining tergites clearly divided into median and lateral plates. Tergite $2+3$ larger than the others, length 1.3, and thus implicitly a fused 'diplotergite'; as in most other trigonotarbids. Paired indents either side of the midline here probably represent muscle apodemes. Tergites $4-6$ shorter, length ca. 0.9 , tergite 7 slightly longer, ca. 1.1. Median plates generally range in width from about 4.0 to 5.0 ; lateral plates may not be preserved at their maximum width (those on the left appear narrower than those on the right) but could be up to ca. 1.3. Tergites 8-9 poorly defined and boundary between them obscure. Unclear whether tergite 9 is also divided into median and lateral plates, but hints of such a division are preserved. Opisthosoma terminates posteriorly in a somewhat pointed end, but given the incompleteness of the preserved morphology we cannot rule out that this is an artefact. Ventral opisthosoma equivocal. A few depressions hint at a slight granulation of the cuticle in life, but in general the dorsal opisthosomal cuticle lacks obvious ornament in the form of large tubercles or pustules (sensu Aphantomartus), although here and for the carapace we would caution that the coarse nature of the tuffaceous matrix could mask any fine ornament originally present in this fossil.

\section{Discussion}

Thirty-four trigonotarbid genera, distributed across nine family groups, are currently recognised as valid in the literature. Note that recent work has recognised numerous generic synonyms among the Anthracomartidae (Garwood \& Dunlop 2011) and future revisions are likely to reduce the total number of genera still further. For completeness, Eurymartus Matthew, 1895 and Elaverimartus Petrunkevitch, 1953 are now regarded as nomina dubia - see Dunlop \& Miller (2007), and Rößler (1998) and Dunlop et al. (in press) for respective explanations. They are excluded from Fig. 5, but as bonefide trigonotarbids their localities are still included in Table 1. A comprehensive cladistic study of relationships among trigonotarbids is lacking, but the sequence of genera presented in this figure reflects recently published ideas on their phylogeny. These include a
Palaeocharinidae-Archaeomartidae-Anthracomartidae group elucidated by Poschmann \& Dunlop (2010, fig. 9), which retain well-developed lateral eye tubercles on a subquadrate, box-like carapace. Another is the 'eophrynid assemblage' (see also above) of KreischeriidaeEophrynidae-Aphantomartidae, postulated by Dunlop \& Brauckmann (2006) on the basis of the putative synapomorphies of a strongly lobed carapace and robust dorsal tuberculation.

\section{Silurian records}

The oldest trigonotarbid genus - Palaeotarbus Dunlop, 1999 - hails from the late Silurian (Pridoli: 419-423 Ma) of Ludford Lane in England (Jeram et al. 1990; Dunlop 1996a, 1999a). This remains the oldest nonscorpion arachnid and, assuming that trigonotarbids were all terrestrial, one of the oldest land-living animals known to date. Its triangular carapace may suggest affinities with the younger family Trigonotarbidae, but details are lacking and it is currently treated as a plesion genus (Fig. 5).

\section{Devonian records}

Stratigraphically, the next trigonotarbid genus is Arianrhoda Dunlop \& Selden, 2004 from the Lochkovian (ca. 411-419 Ma) of Tredomen in Wales. It was placed in the family Anthracosironidae. This is followed by some exquisitely preserved and three-dimensional fossils assigned to Palaeocharinus Hirst, 1923 (Palaeocharinidae) from the Early Devonian (Pragian: ca. $410 \mathrm{Ma}$ ) Rhynie and Windyfield cherts of Scotland (Hirst 1923; Hirst \& Maulik 1926; Fayers et al. 2005). These silicified fossils are unequivocally of terrestrial animals since they exhibit the oldest evidence for air-breathing book lungs (Claridge \& Lyon 1961).

Slightly younger is a further palaeocharinid genus, Spinocharinus Poschmann \& Dunlop, 2011, recently described from Bürdenbach in the German Rhineland and which may also date to the late Pragian. Near contemporary, but perhaps a little younger at Lower Emsian (ca. $405 \mathrm{Ma}$ ) are a series of further Rhineland genera, namely Alkenia Størmer, 1970 and Archaeomartus Størmer, 1970 from Alken an der Mosel (Størmer 1970; Poschmann \& Dunlop 2010). Of these, Alkenia was recently reassigned to Aphantomartidae and $\mathrm{Ar}$ chaeomartus to a new family Archaeomartidae; the latter with characters intermediate between palaeocharinids and anthracomartids (Poschmann \& Dunlop 2010). Further adjacent localities in the German Rhineland, such as Konderbachtal (Brauckmann 1987) and Waxweiler (Brauckmann 1994), have also yielded Alkentype trigonotarbids. The oldest record of Trigonotarbus Pocock, 1911 (Trigonotarbidae) comes from a less clearly defined locality in this region given as the 'Rhenish Slate Mountains' [Rheinisches Schiefergebirge] (Schultka 1991). However, there are some differ- 


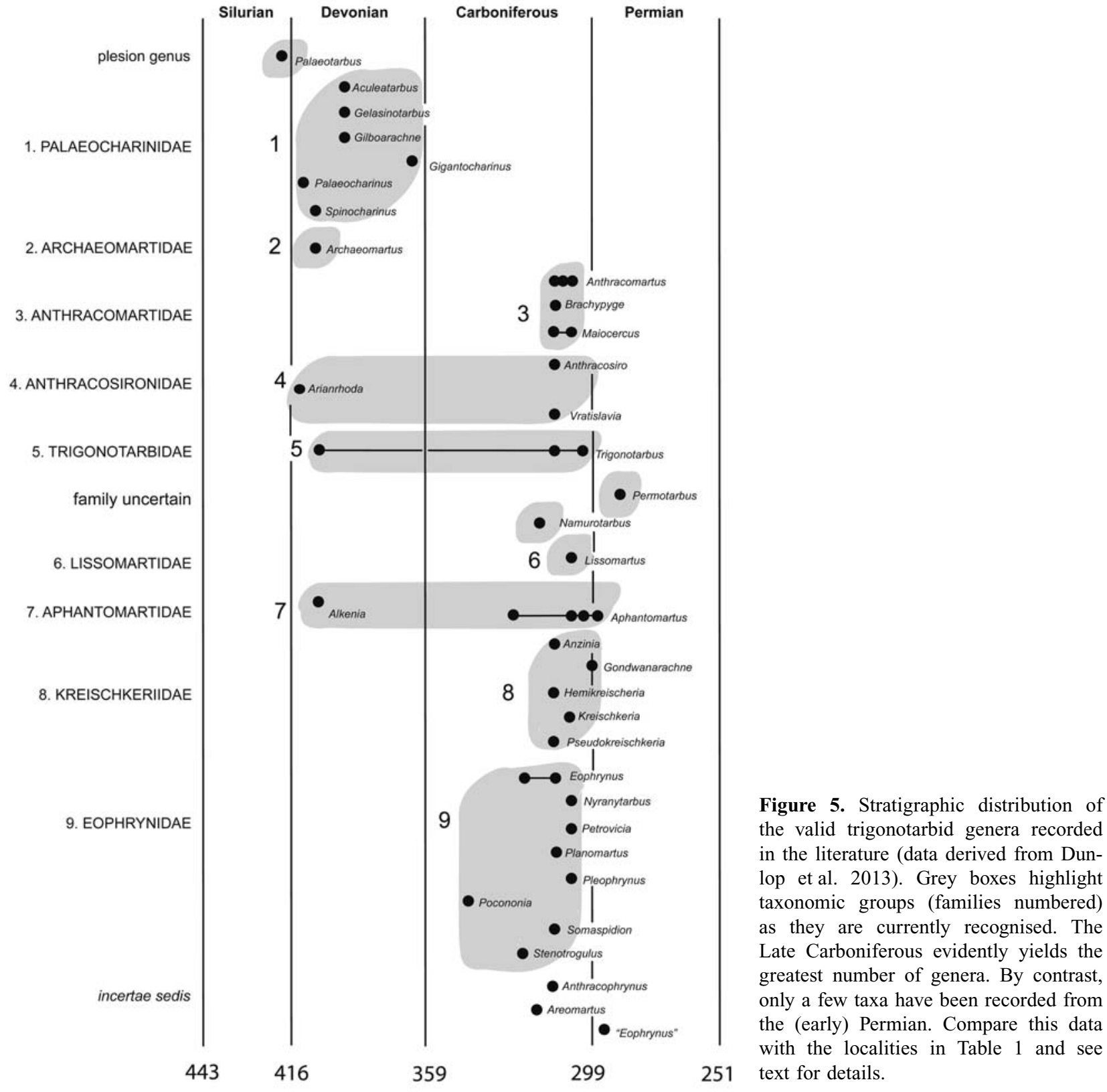

Age (Ma)

ences compared to the Carboniferous type species of the genus and restudy of the original specimen would be welcome to confirm its familial affinities.

Middle Devonian (Givetian: ca. $385 \mathrm{Ma}$ ) sediments have yielded three palaeocharinid trigonotarbid genera as cuticle macerates from the Gilboa Mudstones of New York, USA: namely Aculeatarbus Shear, Selden \& Rolfe, 1987, Gelasinotarbus Shear, Selden \& Rolfe, 1987 and Gilboarachne Shear, Selden \& Rolfe, 1987. The only record from the Late Devonian is also from the USA. The late Famennian (ca. 365? Ma) Gigantocharinus Shear, 2000 comes from Red Hill in Pennsylvania. Although originally assigned to Palaeocharinidae, its tuberculate dorsal surface and lobed carapace suggest that it may be better placed in a more derived family, perhaps Aphantomartidae; see also comments in Dunlop \& Brauckmann (2006).

\section{Carboniferous records}

Early Carboniferous trigonotarbids are rare. Pocononia Petrunkevitch, 1953 derives from the Pocono Formation of Virginia, USA (Ewing 1930; Dunlop 1996b). Its age is usually given as "early Mississippian" - perhaps about 345 Ma? - whereby Pocononia represents the oldest record of the family Eophrynidae. Additionally, Rößler (1998, fig. 17) documented two finds from the late Viséan (ca. $330 \mathrm{Ma}$ ) of the Erzgebirge Basin of Chemnitz in Germany and Kamienna Gora (Intrasudetic Basin) in Poland. Both could be assigned to Aphantomartus Pocock, 1911 (Aphantomartidae) and represent the youngest record of this important, and long-lived genus (see also Correia et al. 2013) which can be traced right through into the Permian (Fig. 5). 
Table 1. The seventy-seven localities known to have yielded trigonotarbid fossils, arranged stratigraphically from youngest (above) to oldest (below). Note the concentration of records from the Late Carboniferous Coal Measures associated with coal mining districts; particularly in the Moscovian (ca. 307-312 Ma) of Europe and North America (see also Figure 6). Stage names and absolute dates derived from the 2012 edition of the 'International Stratigraphic Chart'.

\begin{tabular}{|c|c|c|c|c|c|}
\hline Period & Age/Stage & Locality & Country & Ma & Reference \\
\hline \multirow[t]{6}{*}{ PERMIAN } & Sakmarian & Chemnitz & Germany & $290-295.5$ & this study \\
\hline & Asselian & Ottostollen near Ilfeld & Germany & $295.5-299$ & Scharf (1924) \\
\hline & Asselian & Manebach & Germany & $295.5-299$ & Müller (1957) \\
\hline & Asselian & Sperbersbach & Germany & $295.5-299$ & $\begin{array}{l}\text { unpublished, pers. comm. } \\
\text { Brauner, } 2012\end{array}$ \\
\hline & Asselian & Cabarz & Germany & $295.5-299$ & $\begin{array}{l}\text { unpublished, pers. comm. } \\
\text { Brauner, } 2012\end{array}$ \\
\hline & ?Asselian & Bajo de Véliz & Argentina & $295.5-299$ & Pinto \& Hünicken (1980) \\
\hline \multirow[t]{33}{*}{ CARBON. } & $\begin{array}{l}\text { Gzhelian } \\
\text { [Stephanian] }\end{array}$ & Radvanice & Czech Republic & $299-304$ & Opluštil (1985) \\
\hline & $\begin{array}{l}\text { Gzhelian } \\
\text { [Stephanian C] }\end{array}$ & Plötz near Halle & Germany & $299-304$ & Rößler (1998) \\
\hline & Gzhelian & Steinbach near Brücken & Germany & $299-304$ & Ammon (1901) \\
\hline & Gzhelian & Montceau-les-Mines & France & 299-304 & Dunlop (1999b) \\
\hline & Gzhelian & São Pedro da Cova & Portugal & 299-304 & Correia et al. (2013) \\
\hline & Gzhelian & Guardo, León & Spain & 299-304 & Selden \& Romano (1983) \\
\hline & Gzhelian & Decazeville & France & 299-304 & Petrunkevitch (1955) \\
\hline & Gzhelian & Commentry & France & $299-304$ & Thevenin (1902) \\
\hline & Kasimovian & Lawrence, Kansas & USA & $304-307$ & Wright \& Selden (2011) \\
\hline & Kasimovian & Chunya, Tunguska Basin & Russia & $304-307$ & Eskov (1998) \\
\hline & Kasimovian & Zheltyi Yar, Kusnezk Basin & Russia & $304-307$ & Eskov (1998) \\
\hline & $\begin{array}{l}\text { Moscovian } \\
\text { [Asturian] }\end{array}$ & San Giorgio, Sardinia & Italy & $307-315$ & Selden \& Pillola (2009) \\
\hline & Moscovian & Merlebach & France & $307-315$ & Waterlot (1934) \\
\hline & Moscovian & Kilmersdon / Writhlington & UK & $307-315$ & Ambrose \& Romano (1972) \\
\hline & Moscovian & Glyn-coch & UK & $307-315$ & Pocock (1911) \\
\hline & Moscovian & Maes-y-cwmmer & UK & $307-315$ & Pocock (1911) \\
\hline & Moscovian & Nýřany & Czech Republic & $307-315$ & Frič (1901) \\
\hline & Moscovian & Mazon Creek, Illinois & USA & $307-315$ & Scudder (1884) \\
\hline & Moscovian & Pawtucket, Rhode Island & USA & $307-315$ & Scudder (1893) \\
\hline & Moscovian & Piesberg near Osnabrück & Germany & $307-315$ & Rößler (1998) \\
\hline & Moscovian & Oelsnitz & Germany & $307-315$ & Barthel \& Rößler (1998) \\
\hline & Moscovian & Zwickau & Germany & $307-315$ & Geinitz (1882) \\
\hline & $\begin{array}{l}\text { Moscovian } \\
\text { [Bolsovian] }\end{array}$ & Týnec & Czech Republic & $307-315$ & Tichávek \& Bureš (2010) \\
\hline & Moscovian & $\begin{array}{l}\text { Libušin and Vinařice near } \\
\text { Kladno }\end{array}$ & Czech Republic & $307-315$ & Opluštil $(1985,1986)$ \\
\hline & Moscovian & Ovčin near Pilsen & Czech Republic & $307-315$ & pers. comm. Opluštil, 2012 \\
\hline & Moscovian & Rakovník & Czech Republic & $307-315$ & Kušta (1883) \\
\hline & Moscovian & New Brunswick & Canada & $307-315$ & Miller \& Forbes (2001) \\
\hline & Moscovian & Drilling Rehden 21 & Germany & $307-315$ & Rößler (1995) \\
\hline & Moscovian & Drilling Stangenmühle, Saar & Germany & $307-315$ & Guthörl (1938) \\
\hline & $\begin{array}{l}\text { Moscovian } \\
\text { [Duckmantian] }\end{array}$ & Ibbenbüren & Germany & $307-315$ & van Essen et al. (1997) \\
\hline & Moscovian & Aachen & Germany & $307-315$ & Guthörl (1940) \\
\hline & Moscovian & $\begin{array}{l}\text { Drilling Kuhl } 2 \\
\text { near Dinslaken }\end{array}$ & Germany & $307-315$ & Jux (1982) \\
\hline & Moscovian & Jerusalemsberg & Slovakia & $307-315$ & Vaňová (1987) \\
\hline
\end{tabular}


Table 1. (continued)

\begin{tabular}{|c|c|c|c|c|c|}
\hline Period & Age/Stage & Locality & Country & $\mathrm{Ma}$ & Reference \\
\hline \multirow[t]{29}{*}{ CARBON. } & Moscovian & Lens & France & $307-315$ & Pruvost (1912) \\
\hline & Moscovian & Aniche & France & $307-315$ & Pruvost (1912) \\
\hline & Moscovian & L'Escarpelle & France & $307-315$ & Thevenin (1902) \\
\hline & Moscovian & Anzin & France & $307-315$ & Pruvost (1919) \\
\hline & Moscovian & Shipley & UK & $307-315$ & Moysey (1911) \\
\hline & Moscovian & Crawcrook & UK & $307-315$ & Gill (1909) \\
\hline & Moscovian & Ty'nybedw & UK & $307-315$ & O'Connor (1896) \\
\hline & Moscovian & Coseley & UK & $307-315$ & Woodward (1871) \\
\hline & Moscovian & Coalbrookdale & UK & $307-315$ & Buckland (1837) \\
\hline & $\begin{array}{l}\text { Bashkirian } \\
\text { [Langsettian] }\end{array}$ & Westhoughton & UK & $315-323$ & Gill (1911) \\
\hline & Bashkirian & Ellismuir & UK & $315-323$ & Pocock (1911) \\
\hline & Bashkirian & $\begin{array}{l}\text { 'Fern Ledges', } \\
\text { New Brunswick }\end{array}$ & Canada & $315-323$ & Matthew (1895) \\
\hline & Bashkirian & Joggins, Nova Scotia & Canada & $315-323$ & Petrunkevitch (1913) \\
\hline & Bashkirian & Limbourg & Belgium & $315-323$ & van der Heide (1951) \\
\hline & Bashkirian & Mariemont-Bascoup & Belgium & $315-323$ & Pruvost (1922) \\
\hline & Bashkirian & Rieu-du-Coer & Belgium & $315-323$ & Dorlodot (1922) \\
\hline & Bashkirian & Near Mons & Belgium & $315-323$ & Woodward (1878) \\
\hline & Bashkirian & Nowa Ruda & Poland & $315-323$ & Karsch (1882) \\
\hline & Bashkirian & Kłodzko & Poland & $315-323$ & Römer (1878) \\
\hline & Bashkirian? & Cotton Hill, West Virginia & USA & $315-323$ & Petrunkevitch (1913) \\
\hline & Serpukhovian & Hagen-Vorhalle & Germany & $323-331$ & Brauckmann et al. (1985) \\
\hline & [Namurian B] & & & & \\
\hline & $\begin{array}{l}\text { Serpukhovian } \\
\text { [Namurian A] }\end{array}$ & Nötsch & Austria & $323-331$ & Rößler \& Brauckmann (2000) \\
\hline & Serpukhovian & Ostrava-Karviná & Czech Republic & $323-331$ & Stur (1877) \\
\hline & Serpukhovian & Fayetteville, Arkansas & USA & $323-331$ & Scudder (1884) \\
\hline & late Visean & Drilling Delitzsch 9/64 & Germany & $331-347$ & Kahlert (1998) \\
\hline & Visean & Kamienna Gora & Poland & $331-347$ & Rößler (1998) \\
\hline & Visean & Chemnitz & Germany & $331-347$ & Rößler (1998) \\
\hline & Tournaisian? & Pocono, Virginia & USA & $347-359$ & Ewing (1930) \\
\hline \multirow[t]{10}{*}{ DEVONIAN } & Famennian & Red Hill, Pennsylvania & USA & $359-372$ & Shear (2000) \\
\hline & Givetian & Gilboa, New York & USA & $383-388$ & Shear et al. (1987) \\
\hline & Emsian & 'Rheinisches Schiefergebirge' & Germany & $393-408$ & Schultka (1994) \\
\hline & Emsian & Waxweiler & Germany & $398-408$ & Brauckmann (1994) \\
\hline & Emsian & Konderbachtal & Germany & $398-408$ & Brauckmann (1987) \\
\hline & Emsian & Alken & Germany & $398-408$ & Størmer (1970) \\
\hline & Pragian? & Bürdenbach & Germany & $408-411$ & Poschmann \& Dunlop (2010) \\
\hline & Pragian & Windyfield, Scotland & UK & $408-411$ & Fayers et al. (2005) \\
\hline & Pragian & Rhynie, Scotland & UK & $408-411$ & Hirst (1923) \\
\hline & Lochkovian & Tredomen & UK & $411-419$ & Dunlop \& Selden (2004) \\
\hline SILURIAN & $\mathrm{n} / \mathrm{a}$ & Ludford Lane & UK & $419-423$ & Jeram et al. (1990) \\
\hline
\end{tabular}

Trigonotarbids are found most frequently in the Late Carboniferous Coal Measures of Europe and North America. Stratigraphically, the oldest of these include the Czech genus Stenotrogulus Frič, 1904 (Eophrynidae) from the 'Namurian A' (ca. 325? Ma) corresponding to the Serpukhovian Stage. Another specimen, re- cognised as an aphantomartid (Rößler \& Brauckmann 2000), comes from rocks of a similar age at Nötsch in the Austrian Alps. Slightly younger material comes from the 'Namurian B' (ca. $318 \mathrm{Ma}$ ) of Hagen-Vorhalle in Germany. This includes the first record of the genus Eophrynus Woodward, 1871 (Eophrynidae), as well as 
Namurotarbus Poschmann \& Dunlop, 2010 erected for a fossil originally described under another genus name by Dunlop \& Brauckmann (2006) and currently unplaced at family level.

Numerous trigonotarbid fossils also stem from the Bashkirian, which is more or less equivalent to (or overlaps with) the 'Westphalian A'/Langsettian of traditional European terminology. Notable localities here include Kłodzko [= Glatz] and Nowa Ruda [= Neurode] in Silesia, Poland (Römer 1878; Karsch 1882). These produced, respectively, Vratislavia Frič, 1904 (Anthracosironidae) and the oldest example of Anthracomartus Karsch, 1882 (Anthracomartidae). The other two anthracomartid genera, Maiocercus Pocock, 1911 and Brachypyge Woodward, 1878, also appear in the Bashkirian in England and Belgium respectively. Note that Maiocercus also occurs in continental Europe too and at some slightly younger sites (e.g. van Essen et al. 1997). Contemporary records from further Bashkirian Belgian localities were elucidated by de Dorlodot (1922), Pruvost (1922, 1930) and van der Heide (1951). The incertae sedis genus Areomartus Petrunkevitch, 1913 from West Virginia, USA may also be Bashkirian in age (cf. Dunlop 2010), but its stratigraphy is not well constrained and was only given as "lower Kanawah Formation".

Perhaps the greatest concentration of fossils comes from the Moscovian, roughly equivalent to the Westphalian B-D of the older literature. Important studies covering this fauna include Scudder (1884, 1893), Frič (1901, 1904), Pocock (1911) and Petrunkevitch (1913, 1949, 1953). This ca. 307-315 Ma time frame encompasses many of the classic trigonotarbid localities and, presumably because of this, the highest levels of reported species diversity. These include from the 'Westphalian B' (or Duckmantian) sites such as Aachen (Guthörl 1940) or Ibbenbüren (van Essen et al. 1997) in the Variscan foreland basin; Coseley in the English West Midlands (Pocock 1911) - and other contemporary outcroppings of the British Middle Coal Measures (e.g. Gill 1909; Moysey 1911) - together with Anzin in northern France (Pruvost 1919) and the Jerusalemsberg in eastern Slovakia (Vaňová 1987; Hyžný et al. 2013). Genera first recorded from this time period include Anthracosiro Pocock, 1903 (Anthracosironidae), Anzinia Petrunkevitch, 1953 and Pseudokreischeria Petrunkevitch, 1953 (both Kreischeriidae) and Somaspidion Jux, 1982 (Eophrynidae).

The 'Westphalian C' (or Bolsovian) includes outcrops in the Variscan foreland basin, such as the drilling core 'Rehden 21' in northern Germany, but more frequently, various outcrops in the intermontane area provided trigonotarbid finds. Among these are the Saar Basin of Germany (e.g. Guthörl 1938; Brauckmann 1984) as well as Rakovník, Kladno (summaries in Opluštil 1985, 1986) and the recently discovered Týnec site (Tichávek \& Bureš 2010) in the Central Bohemian Basin of the Czech Republic. The genus Planomartus Petrunkevitch, 1953 (Eophrynidae) appears in rocks of this age in Bohemia.
The 'Westphalian D' includes important localities such as Nýrrany in the Czech Republic, a series of German outcrops (see below), parts of the South Wales coalfield (Pocock 1911), Kilmersdon and the adjacent Writhlington Geological Nature Reserve in south-western England (Ambrose \& Romano 1972), and Rhode Island and Mazon Creek in the USA (Scudder 1884, 1893; Petrunkevitch 1913). Taxa appearing in this stage include the Czech genera Nyranytarbus Harvey \& Selden, 1995 and Petrovicia Frič, 1904 (both Eophrynidae), the German genus Kreischeria Geinitz, 1882 (Kreischeriidae) from Zwickau, the Mazon Creek genus Lissomartus (Lissomartidae), and the more widely distributed Pleophrynus Petrunkevitch, 1945 (Eophrynidae) found in both Europe and the USA. Other German records from this regional substage include aphantomartids from Oelsnitz (Barthel \& Rößler 1998) as well as numerous specimens of Aphantomartus from the classic open cast mine of Piesberg near Osnabrück, northern Germany.

Latest Carboniferous records are, by contrast, rather sparse (Table 1) and the only Kazimovian record is of Anthracomartus sp. from Kansas, USA (Wright \& Selden 2011). Slightly younger (Gzhelian) finds - corresponding to the Stephanian in traditional stratigraphic terminologies (ca. 299-304 Ma) - include a Trigonotarbus from Decazeville in France (cf. Petrunkevitch 1955) and examples of Anthracomartus from near Brücken in Germany (Ammon 1901) and Radvanice in the Czech Republic (Opluštil 1985). Aphantomartus was recorded by Selden and Romano (1983) from León Province in Spain, by Correia et al. (2013) from Portugal, by Rößler (1998) from the Saale Basin at Plötz near Halle, Germany, and by Dunlop (1999b) from Montceau-les-Mines in France. In a conference abstract Eskov (1998) noted further trigonotarbids from the Kasimovian stage, at least one eophrynid from Chunya in the Tunguska Basin and one aphantomartid from Zheltyi Yar in the Kuznetsk Basin (both Russia). Additional arachnids of this age, probably trigonotarbids, were documented from the Saale Basin by Aue \& Rohrlack (2007), but identified under the rather questionable name Orthotarbus longipes Simon, 1971 which implies a different arachnid order: Phalangiotarbida.

\section{Permian records}

The only South American trigonotarbid genus, Gondwanarachne Pinto \& Hünicken, 1980 comes from Bajo de Véliz, San Luiz Province in Argentina. The precise age of this locality has been disputed (see Martins-Neto et al. 2007), but the current consensus seems to be that it is either on (or near) the Carboniferous-Permian boundary. The youngest trigonotarbids are unequivocally Permian in age, but these records are comparatively rare. Some material from the Czech Republic was originally interpreted as Permian (e.g. Frič 1901), although subsequent dating placed all these Bohemian 
localities within the Carboniferous (summarised by Opluštil 1986: fig. 1). Thus the only unequivocal Permian records are those noted in the Introduction from Thuringia (Ilfeld, Manebach, several new, still undescribed ones from Sperbersbach and Cabarz (Stephan Brauner, pers. comm. 2012) and Chemnitz; all associated with the Rotliegend of eastern Germany. Although not yet described, Eskov \& Selden (2005) mentioned a poorly preserved trigonotarbid from the Chekarda locality of the Kungurian stage. Nevertheless, at ca. $290 \mathrm{Ma}$, our new fossil is the youngest recorded trigonotarbid to date (Table 1) and extends their fossil record to approximately 130 million years (i.e. from 420-290 Ma).

\section{Extinctions}

Trigonotarbida is one of four arachnid orders which, on current evidence, did not survive beyond the Palaeozoic. The others are Phalangiotarbida (Devonian-Permian), Haptopoda (Carboniferous) and the recently recognised and spider-like Uraraneida (DevonianPermian). Trigonotarbids are the most species-rich of these extinct orders, with sixty-five currently valid species; as compared to thirty-one phalangiotarbids, one haptopodid and two uraraneid species respectively (cf. Dunlop et al. 2013). Also in terms of raw numbers of fossils, and fossil localities hosting these specimens (Table 1), the general impression is of trigonotarbids having been a fairly common and widespread group; particularly in the Late Carboniferous Coal Measures environments of Europe and North America (Figs 5, 6). They are certainly discovered more frequently as fossils than diverse modern arachnids of at least medium body size like spiders (Araneae) and harvestmen (Opiliones) today. To what extent this reflects genuine palaeodiversity patterns or ecological and/or taphonomic factors is a matter for further discussion. For example most Palaeozoic spiders appear to belong to a clade whose modern representatives (Mesothelae) spend most of their life cycle concealed in burrows today, which would obviously confer a lower fossilisation potential.

In discussing broader diversity patterns among trigonotarbids, and contemporary fossil arachnids, we should also bear in mind that the Carboniferous - and the Coal Measures in particular - were economically significant and intensively mined. Accordingly, the chance of finding specimens was comparatively high both in the coal mines and many years later on the mining spoil heaps. Hence the majority of Palaeozoic arachnid finds are more or less connected with coal exploration or mining and this is strongly reflected in the distribution and nature of the localities seen in Table 1 and Figure 6. By contrast, Permian strata were not of the same level of industrial interest as those of the Carboniferous. A few occurrences with coal were also mined, and these sites have also yielded fossil arachnids (e.g. Ilfeld and Manebach in Germany). Nevertheless, disco- vering arachnid fossils in the Permian was always a rather random event.

It is also worth remarking that trigonotarbids have not (yet) been found in the Early Permian coal deposits of China. In this geographical region the 'European' type of Carboniferous Coal Measures forest persists even into the upper Permian where it yields many typical swamp plants, like the arboreal lycopsids - the majority of which became extinct in Euramerica at the end of the Carboniferous - or calamitaleans. These floral elements probably migrated into Asia towards the end of the $\mathrm{Pa}$ laeozoic and survived in China much longer; see e.g. Wang (2010). Unlike in Europe, fossil plants are abundant in China throughout the entire Permian and are found even just below the Permian-Triassic boundary where they formed coal beds. The latter are currently being heavily mined (and may continue to be mined in the future). In general, the late Palaeozoic is characterised by major climatic changes, such as the transition from an icehouse to a greenhouse world. The floral provincialism starting in the Carboniferous culminated in the Permian during which four major floral provinces can be recognised; all of which are represented in China. We might predict that typical Carboniferous arachnids, including trigonotarbids, may yet be discovered at Asian localities of Permian age which maintained something akin to the typical Coal Measures floras.

A further point to note is that the available sequences belonging to Permian deposits - although reaching considerable thickness - are very rich in hiatuses (Kerp 2000). Thus the sediments rarely reflect the classical arachnid biotopes and exhibit a high amount of extrabasinal material. The Permian is generally characterized by rapid vertical and lateral facies changes and the fossil remains originate from different types of environments and habitats. A large portion of the sediments developed in red bed facies. The preservation potential of organic remains is considerably reduced in an environment prone to erosion, seasonality and overall drying. All things considered, the apparent sudden decline of the trigonotarbids (Fig. 5) may also be a consequence of a chain of different geotectonic processes causing large-scale climatic and ecologic changes resulting in different environments, smaller basins and thus a rather limited fossil record.

Nevertheless, trigonotarbids are no longer with us and it is interesting to speculate about the eventual biological causes of their extinction. For example a Euamerican 'Carboniferous Rainforest Collapse' (CRC) dating to about 305 million years ago has been postulated, at least for tetrapods (e.g. Sahney et al. 2010). This immediately follows the last time period (the Moscovian: ca. 307-315 Ma) from which trigonotarbid fossils are frequently recovered. However, we should stress that at least four trigonotarbid genera (Anthracomartus, Aphantomartus, Trigonotarbus and the southern hemisphere Gondwanarachne) postdate this putative Euamerican CRC event by up to 15 million years (Fig. 5; Table 1). Also, the last recorded species in the Early 

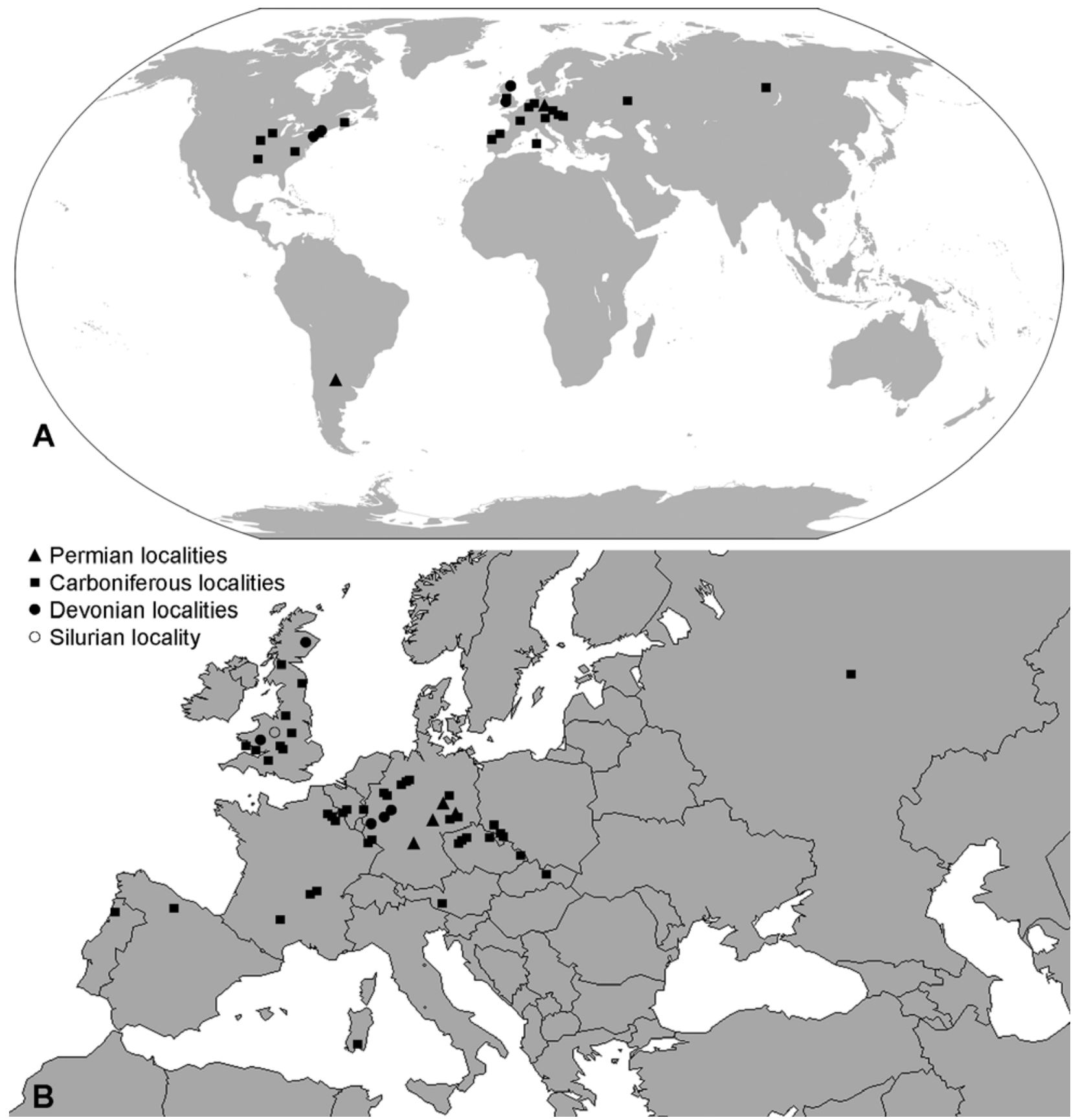

Figure 6. Geographic distribution of the known trigonotarbid localities. A. Global distribution. B. Details for Europe. Note the preponderance of Carboniferous sites - strongly correlating to areas of intensive coal production in the 19th and 20th centuries such as the Saar region, Silesia, Bohemia, the British midlands, etc. - as compared to the relative paucity of Permian sites (Argentina and Germany only).

Permian does not seem to coincide with any particular mass extinction. The next one would be the massive loss of biodiversity at the End Permian event. In any case the current dataset is probably too small for a meaningful statistical analysis. On present data, the most important factor may simply have been the loss of the coal swamps and a general drying of the environment during the Permian. It begs the question why groups like spiders survived these changes and subsequently radiated so spectacularly in the Mesozoic (cf. Selden \& Penney 2010, fig. 2).

\section{Acknowledgements}

We thank the excavation team of the Chemnitz Museum of Natural History, particularly Ralph Kretzschmar, Mathias Merbitz, Volker Annacker and Sandra Mehlhorn. We gratefully acknowledge both the enthusiastic field work help from, and scientific discussions with, Jörg W. Schneider (Freiberg), Ralf Werneburg and Georg Sommer (Schleusingen) and Stephan Brauner (Friedrichroda). We are also indebted to Thorid Zierold for her professional project management and thank the reviewers for helpful comments on the typescript. This research was funded by the Volkswagen Foundation (Az: I/84638). 


\section{References}

Ambrose, T. \& Romano, M. 1972. New Upper Carboniferous Chelicerata (Arthropoda) from Somerset, England. - Palaeontology 15: 569-578.

Ammon, L. von 1901. Ueber Anthracomartus aus dem Pfälzischen Carbon. - Geognostische Jahreshefte 13: 1-6.

Aue, J. \& Rohrlack, E. 2007. Neue Aufsammlungen fossiler Pflanzen und Tiere von den alten Steinkohlenhalden der Saale-Senke. Abhandlungen und Berichte für Naturkunde 30: 147-181.

Barthel, M. \& Rößler, R. 1998. Brennende Berge - Flöz- und Haldenbrand-Gesteine als Matrix fossiler Pflanzen-Abdrücke. - Veröffentlichungen des Museums für Naturkunde Chemnitz 21: 5362.

Berger, H.-J. \& Junghanns, C. 2010. Rotliegend. In Alexowsky, W., Berger, H.-J., Hübner, F., Junghanns, C. \& Wolf, L. (eds). Geologische Karte des Freistaates Sachsen, 1:25,000, Erläuterung zu Blatt 5143 Chemnitz, 4. neu bearbeitete Auflage, Freiberg.

Brauckmann, C. 1984. Eine neue Arachniden-Art aus dem Westfalium des Saargebietes (West-Deutschland). - Dortmunder Beiträge zur Landeskunde, naturwissenschaftliche Mitteilungen 18: 95-103.

Brauckmann, C. 1987. Neue Arachnidenfunde (Scorpionida, Trigonotarbida) aus dem westdeutschen Unter-Devon. - Geologica et Palaeontologica 21: 73-85.

Brauckmann, C. 1994. Zwei neue Arachniden-Funde (Trigonotarbida) aus dem Unter-Devon der Eifel. - Jahresbericht des Naturwissenschaftlichen Vereins in Wuppertal 47: 168-173.

Brauckmann, C., Koch, L. \& Kemper, M. 1985. Spinnentiere (Arachnida) und Insekten aus den Vorhalle-Schichten (Namurian B; Ober-Karbon) von Hagen-Vorhalle (West-Deutschland). - Geologie und Paläontologie in Westfalen 3: 1-132.

Buckland, W. 1837. The Bridgewater Treatises on the power wisdom and goodness of God as manifested in the creation, volume IV: Geology and mineralogy considered with reference to natural theology. William Pickering, London.

Claridge, M. F. \& Lyon, A. G. 1961. Lung-books in the Devonian Palaeocharinidae (Arachnida). - Nature 191: 1190-1191.

Correia, P., Murphy, J. B., Sá, A. A., Domingos, R. \& Flores, D. 2013. First Paleozoic arachnid from Portugal and implications for Carboniferous palaeobiogeography. - Geological Journal 48: 101-107.

Dorlodot, J. de 1922. Un Spécimen nouveau d'Arachnide du Westphalien de la Belgique. - Bulletin de la Société Belge de Géologie 32: 65 .

Dunlop, J. A. 1995. Redescription of the Pennsylvanian trigonotarbid arachnid Lissomartus Petrunkevitch 1949 from Mazon Creek, Illinois. - The Journal of Arachnology 23: 118-124.

Dunlop, J. A. 1996a. A trigonotarbid arachnid from the Upper Silurian of Shropshire. - Palaeontology 39: 605-614.

Dunlop, J. A. 1996b. A redescription of the trigonotarbid arachnid Pocononia whitei (Ewing 1930). - Paläontologische Zeitschrift 70: $145-151$

Dunlop, J. A. 1999a. A replacement name for the trigonotarbid arachnid Eotarbus Dunlop. - Palaeontology 42: 191

Dunlop, J. A. 1999b. A new specimen of the trigonotarbid arachnid Aphantomartus areolatus Pocock 1911 from the Stephanian of Montceau-les-Mines, France. - Neues Jahrbuch für Geologie und Paläontologie, Monatshefte 1999(1): 29-38.

Dunlop, J. A. 2010. The enigmatic Pennsylvanian arachnids Areomartus ovatus and Vratislavia silesica (Trigonotarbida). - The Journal of Arachnology 38: 44-48.

Dunlop, J. A. \& Brauckmann, C. 2006. A new trigonotarbid from the Coal Measures of Hagen Vorhalle, Germany. - Fossil Record 9: $130-136$.

Dunlop, J. A. \& Miller, R. F. 2007. The fossil arachnid genus Eurymartus Matthew, 1895 and the eurypterid genus Eurypterella Matthew, 1889 from the Late Carboniferous "Fern Ledges" of Saint
John, New Brunswick, Canada. - Neues Jahrbuch für Geologie und Paläontologie, Abhandlungen 245: 295-300.

Dunlop, J. A. \& Selden, P. A. 2004. A trigonotarbid arachnid from the Lower Devonian of Tredomen, Wales. - Palaeontology 47: 1469-1476.

Dunlop, J. A., Penney, D. \& Jekel, D. 2013. A summary list of fossil spiders and their relatives. In Platnick, N. I. (ed.) The world spider catalog, version 13.5. American Museum of Natural History, online at http://research.amnh.org/iz/spiders/catalog. DOI: 10.5531/db.iz.0001.

Dunlop, J. A., Ross, A. J. \& Steward, S. E. in press. The Ellismuir fossil arachnid - the only known Scottish Carboniferous trigonotarbid. - Scottish Journal of Geology.

Eskov K. Y. 1998. First records of trigonotarbids (Arachnida: Trigonotarbida) in the Carboniferous of cool-temperate Angarian Realm. - First Paleoentomological Conference, Moscow, 1998, Abstracts: 5

Eskov, K. Y. \& Selden, P. A. 2005. First record of spiders from the Permian period (Araneae: Mesothelae). - Bulletin of the British arachnological Society 13: 111-116.

Essen H. van, Steur, H. \& Brauckmann, C. 1997. Spinachtigen uit het carboon van Ibbenbüren. Maiocercus celticus. - Grondboor en Hamer 1997 (3/4): 62-70.

Ewing, H. E. 1930. A fossil arachnid from the Lower Carboniferous shales (Pococno formation) of Virginia. - Annals of the Entomological Society of America 23: 641-643.

Fayers, S. R., Dunlop. J. A. \& Trewin, N. H. 2005. A new early Devonian trigonotarbid arachnid from the Windyfield chert, Rhynie, Scotland. - Journal of Systematic Palaeontology 2: 269-284.

Frič, A. 1901. Fauna der Gaskohle und der Kalksteine der Permformation Böhmens. Vol. IV, part 2. Myriopoda pars II. Arachnoidea, pp. 56-63, pls 153, 154, Prague.

Frič, A. 1904. Palaeozoische Arachniden. A. Frič, Prague.

Garwood, R. J. \& Dunlop, J. A. 2011. Morphology and systematics of Anthracomartidae (Arachnida: Trigonotarbida). - Palaeontology 54: $145-161$.

Geinitz, H. B. 1882. Kreischeria wiedei, ein Pseudoskorpion aus der Steinkohlenformation von Zwickau. - Zeitschrift der Deutschen Geologischen Gesellschaft 34: 238-242.

Gill, E. L. 1909. An arachnid from the Coal Measures of the Tyne Valley. - Transactions of the Natural History Society of Northumberland, Durham and Newcastle-upon-Tyne 3: 510-523.

Gill, E. L. 1911. A Carboniferous arachnid from Lancashire. - Geological Magazine 5(8): 395-398.

Guthörl, P. 1938. Eophrynus waechteri n. sp. (Arachn., Anthracom.) aus der Tiefbohrung Stangenmühle, Saar-Karbon. - Senckenbergiana 20: 465-470.

Guthörl, P. 1940. Zur Arthropoden-Fauna des Karbons und Perms. 10. Trigonomartus pustulatus (Scudder) (Arach., Anthracom.) aus der Grube Nordstern, Aachener Karbon. - Paläontologische Zeitschrift 22: 63-74.

Harvey, M. A. \& Selden, P. A. 1995. Nyranytarbus, replacement name for Hemiphrynus Frič, 1901 (Trigonotarbida: Eophrynidae). Bulletin of the British arachnological Society 10: 74 .

Heide, S. van der 1951. Les arthropodes du terrain houiller du Limbourg méridional (excepté les scorpions et les insectes). - Mededeelingen van de Geologische Stichting, Serie C, IV (3) (5): 184.

Hirst, S. 1923. On some arachnid remains from the Old Red Sandstone (Rhynie chert Bed, Aberdeenshire). - Annals and Magazine of Natural History, Series 9 12: 455-474.

Hirst, S. \& Maulik, S. 1926. On some arthropod remains from the Rhynie Chert (Old Red Sandstone). - Geological Magazine 63: 69-71.

Hyžný, M., Jósza, S., Dunlop, J. A. \& Selden, P. A. 2013. A fossil arachnid from Slovakia: the Carboniferous trigonotarbid Anthracomartus voelkelianus Karsch, 1882. - Arachnology 16: 21-26.

Jeram, A. J., Selden, P. A. \& Edwards, D. 1990. Land animals in the Silurian: arachnids and myriapods from Shropshire, England. Science 250: 658-661. 
Jux, U. 1982. Somaspidion hammapheron n. gen. n. sp. - ein Arachnide aus dem Oberkarbon der subvaristischen Saumsenke NW Deutschlands. - Paläontologische Zeitschrift 56: 77-86.

Kahlert, E. 1998. Ein Arachniden-Opisthosoma aus dem Obervisé von NW-Sachsen. - Mitteilungen des Museums für Naturkunde Berlin, Geowissenschaftliche Reihe 1: 135-138.

Karsch, F. 1882. Ueber ein neues Spinnenthier aus der Schlesischen Steinkohle und die Arachnoiden überhaupt. - Zeitschrift der Deutschen Geologischen Gesellschaft 34: 556-561.

Kerp, H. 2000. The modernization of landscapes during the Late Paleozoic-Early Mesozoic. In Gastaldo, R. A. \& DiMichele, W. A. (eds). Phanerozoic terrestrial ecosystems. - The Paleontological Society Papers 2000 (6): 79-113.

Kretzschmar, R., Annacker, V., Eulenberger, S., Tunger, B. \& Rößler, R. 2008. Erste wissenschaftliche Grabung im Versteinerten Wald von Chemnitz - ein Zwischenbericht. - Freiberger Forschungshefte, C 528: 25-55.

Kušta, J. 1883. Anthracomartus krejcii, eine neue Arachnide aus dem Böhmischen Karbon. - Sitzungsberichte der Königlich Böhmischen Gesellschaft der Wissenschaften, Mathematisch-Naturwissenschaftliche Klasse 1883: 7.

Martins-Neto, R. G., Gallego, O. F., Brauckmann, C. \& Cruz, J. L. 2007. A review of the South American Palaeozoic entomofauna Part I: the Ischnoneuroidea and Cacurgoidea, with description of new taxa. - African Invertebrates 48: 87-101.

Matthew, G. F. 1895. Organic remains of the Little River Group, No. IV. - Transactions of the Royal Society of Canada, $2^{\text {nd }}$ Ser. 1 : $273-279$.

Miller, R. F. \& Forbes, W. H. 2001. An Upper Carboniferous trigonotarbid, Aphantomartus pustulatus (Scudder, 1884), from the Maritimes Basin (Euramerican Coal Province), New Brunswick, Canada. - Atlantic Geology 37: 191-196.

Moysey, L. 1911. On some arthropod remains from the Nottinghamshire and Derbyshire Coal-field. - Geological Magazine 5(8): 497-507.

Müller, A. H. 1957. Ein Arachnidenrest (Brachylycosa ? manebachensis n. sp.) aus dem Unteren Rotliegenden (Manebacher Schichten) von Thüringen. - Geologie 6: 95-98.

O'Connor, W. 1896. On several fossils including a 'spider' (Eophry$n u s$ ) from the $9 \mathrm{ft}$ Coal Seam at Tyy'nybedw, Rhondda Valley. Reports and Transactions of the Cardiff Naturalists' Society 28: $50-52$.

Opluštil, S. 1985. New findings of Arachnida from the Bohemian Upper Carboniferous. - Véstnik Ústředního ústavu geologického 60: $35-42$.

Opluštil, S. 1986. Promygale janae sp. n., the new anthracomartid (Arachnida) from the Upper Carboniferous of central Bohemia. Véstnik Ústředního ústavu geologického 61: 287-291.

Petrunkevitch, A. I. 1913. A monograph of the terrestrial Palaeozoic Arachnida of North America. - Transactions of the Connecticut Academy of Arts and Sciences 18: 1-137.

Petrunkevitch, A. I. 1949. A study of Palaeozoic Arachnida. - Transactions of the Connecticut Academy of Arts and Sciences 37: 69-315.

Petrunkevitch, A. I. 1953. Palaeozoic and Mesozoic Arachnida of Europe. - Memoirs of the Geological Society of America 53: 1128.

Petrunkevitch, A. I. 1955. Trigonotarbus arnoldi, a new species of fossil arachnid from southern France. - Journal of Palaeontology 29: 475-477.

Pinto, I. D. \& Hünicken, M. A. 1980. Gondwanarachne a new genus of the Trigonotarbida from Argentina. - Boletin de la Academia Nacional de Ciencias 53: 307-315.

Pocock, R. I. 1903. A new Carboniferous arachnid. - Geological Magazine 4 (10): 247-251.

Pocock, R. I. 1911. A monograph of the terrestrial Carboniferous Arachnida of Great Britain. - Monographs of the Palaeontographical Society 64: 1-84.
Poschmann, M. \& Dunlop, J. A. 2010. Trigonotarbid arachnids from the Lower Devonian (Lower Emsian) of Alken an der Mosel (Rhineland-Palatinate, SW Germany). - Paläontologische Zeitschrift 84: 467-484.

Poschmann, M. \& Dunlop, J. A. 2011. Trigonotarbid arachnids from the Lower Devonian (Siegenian) of Bürdenbach (Lahrbach Valley, Westerwald area, Rhenish Slate Mountains, Germany). - Paläontologische Zeitschrift 85: 433-447.

Pruvost, P. 1912. Note sur les araignées du terrain houiller du Nord de la France. - Annales de la Société Géologique du Nord 41: 85-100.

Pruvost, P. 1919. Introduction à l'étude du terrain houiller du Nord et du Pas-de Calais: La Faune continentale du terrain houiller du Nord de la France. Thesis, University of Lille.

Pruvost, P. 1922. Les Arachnides fossiles du Houiller de Belgique. - Annales de la Société Scientifique de Bruxelles 41: 349_ 353.

Pruvost, P. 1930. La fauna continentale du terrain houiller de la Belgique. - Mémoires du Musée Royal d'Histoiré Naturelle de Belgique 44: 206-217.

Römer, F. 1878. Auffindung und Vorlegung eines neuen Gliederthieres in dem Steinkohlengebiete der Ferdinandgrube bei Glatz. - Jahresbericht der Schlesischen Gesellschaft für Vaterländische Kultur 56: 54-55.

Rößler, R. 1995. Litho- und Biofaziesmuster des kontinentalen Oberkarbon und Rotliegend in Norddeutschland - Grundlagen für die stratigraphische Interpretation von Tiefbohrungen. - Dissertation, Institut für Geologie, TU Bergakademie Freiberg, 122 S., 24 Taf., 20 Abb., 22 Anl., Freiberg.

Rößler, R. 1998. Arachniden-Neufunde im mitteleuropäischen Unterkarbon bis Perm - Beitrag zur Revision der Familie Aphantomartidae Petrunkevitch 1945 (Arachnida, Trigonotarbida). - Paläontologische Zeitschrift 72: 67-88.

Rößler, R. \& Brauckmann, C. 2000. Der erste Arachnidenfund im Paläozoikum der Alpen: Aphantomartus pustulatus (Scudder 1884) aus dem ältesten Ober-Karbon (mittleres bis oberes Namurium A) von Nötsch (Österreich). - Jahrbuch der Geologischen Bundesanstalt 142: 227-234.

Rößler, R., Dunlop, J. A. \& Schneider, J. W. 2003. A redescription of some poorly known Rotliegend arachnids from the Lower Permian (Asselian) of the Ilfeld and Thuringian Forest Basins, Germany. Paläontologische Zeitschrift 77: 417-427.

Rößler, R., Kretzschmar, R., Annacker, V. \& Mehlhorn, S. 2009. Auf Schatzsuche in Chemnitz - Wissenschaftliche Grabungen '09. Veröffentlichungen des Museums für Naturkunde Chemnitz 32: 25-46.

Rößler, R., Zierold, T., Feng, Z., Kretzschmar, R., Merbitz, M., Annacker, V. \& Schneider, J. W. 2012. A snapshot of an Early Permian ecosystem preserved by explosive volcanism: new results from the Petrified Forest of Chemnitz, Germany. - Palaios 27: $814-834$.

Sahney, S., Benton, M. J. \& Falcon-Lang, H. 2010. Rainforest collapse triggered Carboniferous tetrapod diversification in Euramerica. - Geology 38: 1079-1082.

Scharf, W. 1924. Beitrag zur Geologie des Steinkohlengebietes im Südharz. - Jahrbuch des Halleschen Verbands für die Erforschung der Mitteldeutschen Bodenschätze und ihrer Verwaltung 4: 404437

Schneider, J. W. \& Werneburg, R. 2006. Insect biostratigraphy of the Euramerican continental Late Pennsylvanian and Early Permian. In Lucas, S. G., Cassinis, G. \& Schneider, J. W. (eds). Non-Marine Permian Biostratigraphy and Biochronology. - Geological Society, London, Special Publications 265: 325-336.

Schultka, S. 1994. Trigonotarbus stoermeri n. sp. - ein Spinnentier aus den Bensberger Schichten (Ems/Unter-Devon) des Rheinischen Schiefergebirges. - Neues Jahrbuch für Geologie und Paläontologie Abhandlungen 183: 375-390. 
Scudder, S. H. 1884. A contribution to our knowledge of Palaeozoic Arachnida. - Proceedings of the American Academy of Arts and Science 20: 15-22.

Scudder, S. H. 1893. Insect fauna of the Rhode-Island Coal-field. United States Geological Survey, Bulletin No. 101.

Selden, P. A. \& Penney, D. 2010. Fossil spiders. - Biological Reviews 85: 171-206

Selden, P. A. \& Pillola, G. L. 2009. A trigonotarbid arachnid from the Upper Carboniferous of the San Giorgio Basin, Sardinia. Rivista Italiana di Paleontologia e Stratigrafia 115: 269-274.

Selden, P. A. \& Romano, M. 1983. First Palaeozoic arachnid from Iberia: Aphantomartus areolatus Pocock (basal Stephanian; Prov. León, N.W. Spain), with remarks on aphantomartid taxonomy. Boletín del Instituto Geológico y Minero de España 94: 106-112.

Shear, W. A. 2000. Gigantocharinus szatmaryi, a new trigonotarbid arachnid from the Late Devonian of North America (Chelicerata, Arachnida, Trigonotarbida). - Journal of Paleontology 74: 25-31.

Shear, W. A., Selden, P. A., Rolfe, W. D. I., Bonamo, P. M. \& Grierson, J. D. 1987. New terrestrial arachnids from the Devonian of Gilboa, New York (Arachnida, Trigonotarbida). - American Museum Novitates 2901: 1-74.

Simon, R. 1971. Neue Arthropodenfunde aus dem Stephan der Halleschen Mulde. - Bericht der Deutschen Gesellschaft für Geologische Wissenschaften, Reihe A: Geologie/Paläontologie 16: 53-62.

Størmer, L. 1970. Arthropods from the Lower Devonian (Lower Emsian) of Alken an der Mosel, Germany. Part 1: Arachnida. Senckenbergiana lethaea 51: 335-369.
Stur, D. 1877. Die Culm-Flora der Ostrauer und Waldenburger Schichten. - Abhandlungen der königlichen geologischen Reichsanstalt 4: 5 .

Thévenin, A. 1902. Sur une aragnée du terrain houiller de Valenciennes. - Procès-Verbaux de la Société d'Histoire Naturelle Autun 15: 195-203.

Tichávek, F. \& Bureš, J. 2010. Karbonská flóra a vzácné faunistické nálezy na odvalu dolu Austrie 2 v Týnci. - Erica, Plzeň 17: 131140.

Vaňová, M. 1987. Paleontological characteristics of some species from the Jeruzalemský vrch mountain near Dobsiná. - Zápandné Karpaty, sér. paleontológia 12: 47-68.

Wang, J. 2010. Late Paleozoic macrofloral assemblages from Weibei Coalfield, with reference to vegetational change through the Late Paleozoic Ice-age in the North China Block. - International Journal of Coal Geology 83: 292-317.

Waterlot, G. 1934. Étude de la faune continentale de terrain houiller sarro-lorrain. Thesis, University of Lille.

Woodward, H. 1871. On the discovery of a new and very perfect Arachnide from the ironstone of the Dudley Coal-field. - Geological Magazine 1(9): 1-4.

Woodward, H. 1878. Discovery of the remains of a fossil crab (Decapoda, Brachyura) in the Coal-Measures of the environs of Mons, Belgium. - Geological Magazine 2(5): 433-436.

Wright, D. F. \& Selden, P. A. 2011. A trigonotarbid arachnid frm the Pennsylvanian of Kansas. - Journal of Paleontology 85: 871876. 